\title{
Identification of genes expressed in cultures of $E$. coli lysogens carrying the Shiga toxin-encoding prophage $\Phi 24_{B}$
}

\author{
Laura M Riley ${ }^{1,2 \dagger}$, Marta Veses-Garcia ${ }^{1 \dagger}$, Jeffrey D Hillman³ ${ }^{3}$ Martin Handfield ${ }^{3}$, Alan J McCarthy ${ }^{1}$ and
} Heather E Allison ${ }^{1 *}$

\begin{abstract}
Background: Shigatoxigenic E. coli are a global and emerging health concern. Shiga toxin, Stx, is encoded on the genome of temperate, lambdoid Stx phages. Genes essential for phage maintenance and replication are encoded on approximately $50 \%$ of the genome, while most of the remaining genes are of unknown function nor is it known if these annotated hypothetical genes are even expressed. It is hypothesized that many of the latter have been maintained due to positive selection pressure, and that some, expressed in the lysogen host, have a role in pathogenicity. This study used Change Mediated Antigen Technology (CMAT) ${ }^{\mathrm{TM}}$ and 2D-PAGE, in combination with RT-qPCR, to identify Stx phage genes that are expressed in E. coli during the lysogenic cycle.

Results: Lysogen cultures propagated for 5-6 hours produced a high cell density with a low proportion of spontaneous prophage induction events. The expression of 26 phage genes was detected in these cultures by differential 2D-PAGE of expressed proteins and CMAT. Detailed analyses of 10 of these genes revealed that three were unequivocally expressed in the lysogen, two expressed from a known lysogenic cycle promoter and one uncoupled from the phage regulatory network.
\end{abstract}

Conclusion: Propagation of a lysogen culture in which no cells at all are undergoing spontaneous lysis is impossible. To overcome this, RT-qPCR was used to determine gene expression profiles associated with the growth phase of lysogens. This enabled the definitive identification of three lambdoid Stx phage genes that are expressed in the lysogen and seven that are expressed during lysis. Conservation of these genes in this phage genome, and other Stx phages where they have been identified as present, indicates their importance in the phage/lysogen life cycle, with possible implications for the biology and pathogenicity of the bacterial host.

\section{Background}

Shigatoxigenic Escherichia coli (STEC) cause disease in humans following colonisation of the intestinal tract [1]. These infections are often serious, presenting with severe diarrhoea accompanied by haemorrhagic colitis. Downstream sequelae such as haemolytic uraemic syndrome (HUS) and thrombotic thrombocytopenic purpura (TTP) can be fatal $[2,3]$.

The principle defining virulence determinant of all STEC strains is the production of Shiga toxin (Stx), also

\footnotetext{
* Correspondence: hallison@liv.ac.uk

+ Contributed equally

${ }^{1}$ Microbiology Research Group, Institute of Integrative Biology, University of Liverpool, BioSciences Building, Crown Street, Liverpool L69 7ZB, UK

Full list of author information is available at the end of the article
}

known as verocytotoxin (VT) or Shiga-like toxin (SLT) (1), of which there are two distinct forms, Stx1 and Stx2 [4]. Two variants of Stx1 have been identified [5,6], whilst Stx2 is heterogeneous, with some variants more frequently associated with serious STEC outbreaks $[1,7]$. The $s t x$ genes are carried by temperate lambdoid bacteriophages, which enter either the lytic or the lysogenic pathways upon infection of a bacterial cell [8-10]. Any bacteriophage encoding Stx is termed an Stx phage, and there is much genotypic and phenotypic diversity within this loosely-defined group [11]. Integrated Stx phages may exist in the bacterial chromosome as inducible prophages, or their residence within a host cell may facilitate recombination events leading to the loss of prophage sequences, resulting in uninducible, remnant

\section{Biomed Central}


Stx prophages within the lysogen chromosome [12]. The stx genes are located with genes involved in the lytic cycle; hence Shiga toxin expression occurs when Stx phages are induced into this pathway $[11,13]$.

Stx phages possess genomes that are generally $\sim 50 \%$ larger than that of the first described lambdoid phage, $\lambda$ itself, and $\sim 74 \%$ of Stx phage genes have not been definitively assigned a function [11]. Genes that are essential for the Stx phage lifestyle are carried on approximately $30 \mathrm{~kb}$ of DNA [14], whilst the entire genome is ca $60 \mathrm{~kb}$ in size in most cases $[11,15,16]$. The impact of Stx prophage carriage on the pathogenicity profile or biology of the host, beyond conferring the ability to produce Shiga toxin, has remained largely unexplored and it can be suggested that the accessory genome of Stx phages is likely to encode functions for which there has been positive selection [11].

In this paper, we describe the use of proteomic-based protein profile comparisons and Change Mediated Antigen Technology ${ }^{\mathrm{TM}}$ (CMAT) (Oragenics Inc.) [17] to identify Stx phage genes that are expressed during the lysogenic pathway. An E. coli lysogen of $\Phi 24_{B}:$ Kan, in which a kanamycin-resistance cassette interrupts the $\operatorname{stx}_{2} A$ gene [18] of a phage isolated from an E. coli O157:H7 disease outbreak strain, was subjected to both CMAT and two dimensional polyacrylamide gel electrophoresis (2D-PAGE) analyses of the expressed proteome. The $\Phi 24_{\mathrm{B}}::$ Kan genome is $57.6 \mathrm{~kb}$ in size and is identical in all aspects to its wild-type parental phage other than the $\operatorname{stx} A$ gene interruption $[14,18]$. The majority of genes and coding sequences (CDS) carried by $\Phi 24_{\mathrm{B}}$ are simply annotated as hypothetical [GenBank: HM_208303]. Bacteriophages tightly regulate expression of their genes involved in maintenance of lysogeny versus replication of viral progeny, and the differentiation of gene expression associated with each state needed to be carefully determined in order to definitively associate expressed proteins and their genes with either the temperate or the lytic cycle.

\section{Results}

The rate of spontaneous lysis in an E. coli MC1061( $\left.\$ 24_{B}\right)$ culture at different stages of growth

Spontaneous induction, defined as the induction of prophages from lysogens in the absence of an applied stimulus [19], occurs constantly in a proportion of the lysogen population in any culture, and this could seriously interfere with the differentiation of gene expression between lytic and lysogenic states. In this study, it was necessary to determine culture conditions under which the number of spontaneous induction events was low whilst the cell density was high, enabling the consistent harvesting of sufficient amounts of cell-associated protein for downstream analyses. Lysogen cultures were sampled at hourly intervals beginning two hours post inoculation, and the c.f.u. $\mathrm{ml}^{-1}$ and p.f.u. $\mathrm{ml}^{-1}$ determined. The lowest ratio of infective phages to cells, 1:50, occurred at both $2 \mathrm{~h}$ and $3 \mathrm{~h}$ of lysogen growth. However the c.f.u. $\mathrm{ml}^{-1}$ during these times was relatively low; $\mathrm{OD}_{600}=0.184( \pm 0.003)$ and $\mathrm{OD}_{600}=0.651( \pm$ $0.008)$, respectively. The ratio of phage to host cells increased sharply after $4 \mathrm{~h}$ of growth, before dropping after $5 \mathrm{~h}$ to $1: 33(\mathrm{OD} 600=1.192[ \pm 0.011])$. The ratio of phage to cells in the culture remained stable at 1:33 through to 6 hours of growth. Lysogen growth conditions were therefore standardised for MC1061 (Ф24 $\left.4_{B}\right)$ at 5-6 hours when the cells were grown to an $\mathrm{OD}_{600}$ of 1.2-1.3.

\section{Phage-encoded, lysogen-culture gene expression identified by CMAT}

A total of 13,519 clones were subjected to CMAT primary screening, and taking efficiency of the library into account, this equates to a $3.3 x$ coverage of the phage genome. Of these, 330 were identified by the lysogenspecific antiserum and chosen for further analyses and secondary screening. After two rounds of secondary screening, 250 clones were removed from the study and PCR analysis of the remaining 80 clones demonstrated that 46 possessed vector DNA only. The remaining 34 recombinant transformants produced a peptide recognised by antibodies in the lysogen specific antiserum. The cloned inserts were sequenced, and the DNA sequences translated in all six possible reading frames. Twenty-three of the clones possessed sequences from twenty different $\Phi 24_{\mathrm{B}}$ CDS (Table 1, Figure 1). The remaining eleven clones did not align with any $\Phi 24_{B}$ -encoded CDS, although six did possess non-coding regions of the phage genome. The other five clones contained plasmid DNA only.

\section{Phage-encoded, lysogen-culture gene expression identified by 2D-PAGE}

Reproducible sets of gels from 2D-PAGE analyses were obtained through the utilisation of IPG strips in the $\mathrm{pH}$ ranges of 3.5-5.6 and 5.3-6.5. The optimal protein concentration loaded on the gels was found to be $200 \mu \mathrm{g}$ of total cellular protein from crude cell lysates. A total of 42 protein spots were found only in the lysogen gel sets (data not shown); these were excised from the gels and analysed by MALDI-TOF. Twenty-four of these spots (Figure 2) contained enough protein for the generation of mass spectral data. When these spectra were searched against the University of Liverpool MASCOT database, which included all of the $\Phi 24_{\mathrm{B}}$ genome predicted proteins, six samples matched predicted phage proteins (P1 to P6, Table 2, Figure 1). The remaining 20 spots were identified as $E$. coli proteins (Table 2); these are 
Table 1 CDS identified by CMAT and location on the Ф24 ${ }_{B}$ genome

\begin{tabular}{|c|c|c|c|}
\hline Clone & $\begin{array}{l}\text { Alignment to } \Phi 24_{B} \\
\text { genome }\end{array}$ & Aligned CDS & $\begin{array}{c}\text { Possible } \\
\text { gene }\end{array}$ \\
\hline CM1 & 39370-39772 & $38090-40027$ & tspS \\
\hline $\begin{array}{l}\mathrm{CM} 2+ \\
\mathrm{CM} 14\end{array}$ & 17489-18104 & 17559-18086 & dam \\
\hline \multirow[t]{2}{*}{$\mathrm{CM} 3$} & $2523-2185$ & a: 2378-2286 & \\
\hline & & b: 2507-2379 & \\
\hline \multirow[t]{3}{*}{ CM4 } & $3025-2375$ & a: $2545-2375$ & \\
\hline & & b: 2812-2711 & \\
\hline & & c: 2911-2840 & \\
\hline CM5 & 54385-53866 & 53693-53866 & \\
\hline CM6 & 53690-53235 & 53482-53297 & \\
\hline $\begin{array}{l}\mathrm{CM} 7+ \\
\mathrm{CM} 13\end{array}$ & 55160-55667 & $49148-57571$ & \\
\hline CM8 & 38754-39248 & $38460-38954$ & \\
\hline CM9 & $2542-2940$ & $2248-2646$ & \\
\hline CM10 & 35049-34598 & 33695-34702 & \\
\hline $\begin{array}{c}\mathrm{CM} 11+ \\
\mathrm{CM} 12\end{array}$ & $39573-40016$ & 40189-39355 & \\
\hline CM15 & 40137-40506 & $40345-40626$ & \\
\hline CM16 & $38041-37623$ & $38000-37698$ & \\
\hline CM17 & $52465-52147$ & 52191-52514 & \\
\hline CM18 & $45227-45877$ & 44818-45552 & lom \\
\hline CM19 & $45610-46100$ & 45981-46382 & \\
\hline CM20 & $4098-3676$ & $4333-4052$ & \\
\hline CM21 & 39305-39919 & 39405-39650 & \\
\hline $\mathrm{CM} 22$ & $39875-40526$ & 39909-40298 & \\
\hline \multirow[t]{2}{*}{$\mathrm{CM} 23$} & 45713-46232 & $\begin{array}{c}\text { a: } 45784- \\
45921\end{array}$ & \\
\hline & & $\begin{array}{l}\text { b: } 46072- \\
46239\end{array}$ & \\
\hline
\end{tabular}

potentially lysogen specific but were not investigated further here.

\section{Analyses of gene expression patterns}

Generally, lambdoid phage regulatory circuits tightly control the expression of genes, yet some of the genes identified in the CMAT library and the 2D-PAGE analyses above were phage genes whose expression should be linked to prophage induction (Figure 1) and not the stable prophage state, e.g. the gene encoding the tail spike protein. It was assumed that gene expression normally linked to the lytic replication cycle must be at a very high level in a small subset of the cells and that lysogen-restricted gene expression patterns of these genes might be very low, especially as neither CMAT nor 2D-PAGE identified the expression of repressor, the product of the $c I$ gene, in the lysogen culture. Therefore it was essential to devise a method that would determine whether phage genes were being expressed by the majority of the stable lysogen population, or the small

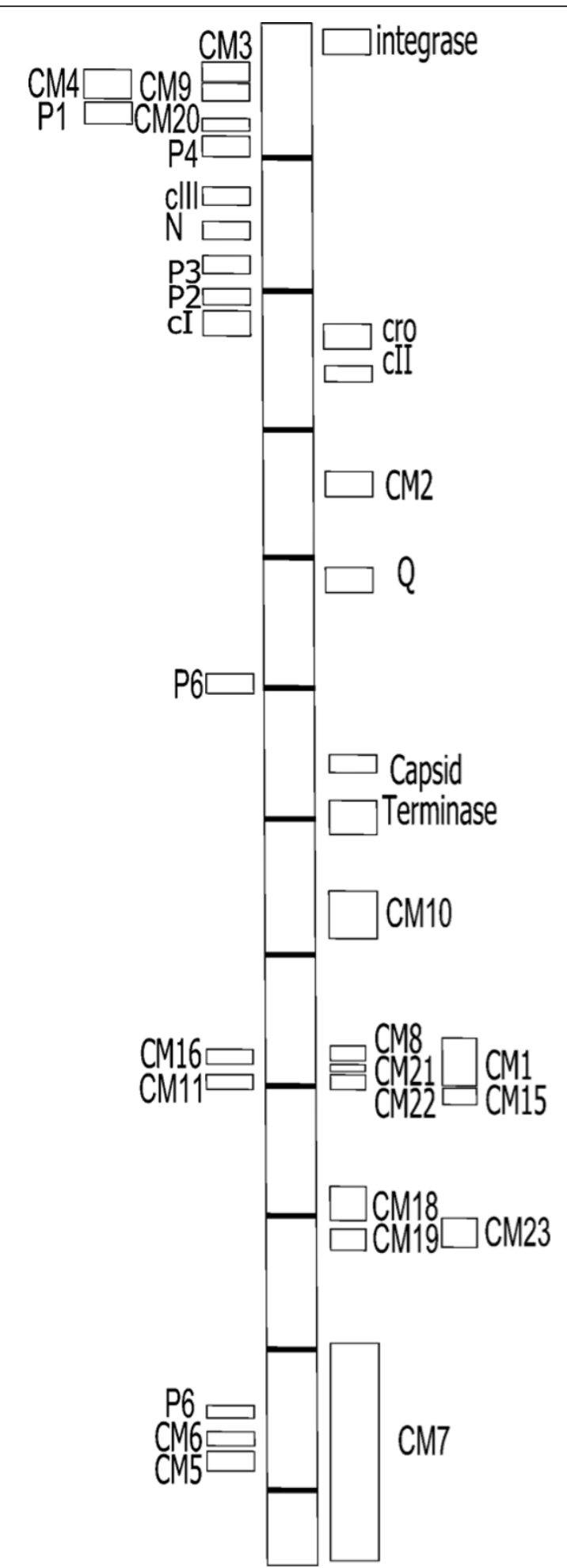

Figure 1 Schematic representation of the $\Phi 24_{B}$ genome Squares symbolise the locations of the CMAT and PAGE CDS identified as well as some of the essential genes involved in the life cycle of the phage. - represents $5 \mathrm{~kb}$. For further details on the gene identities see Tables $1 \& 2$. 

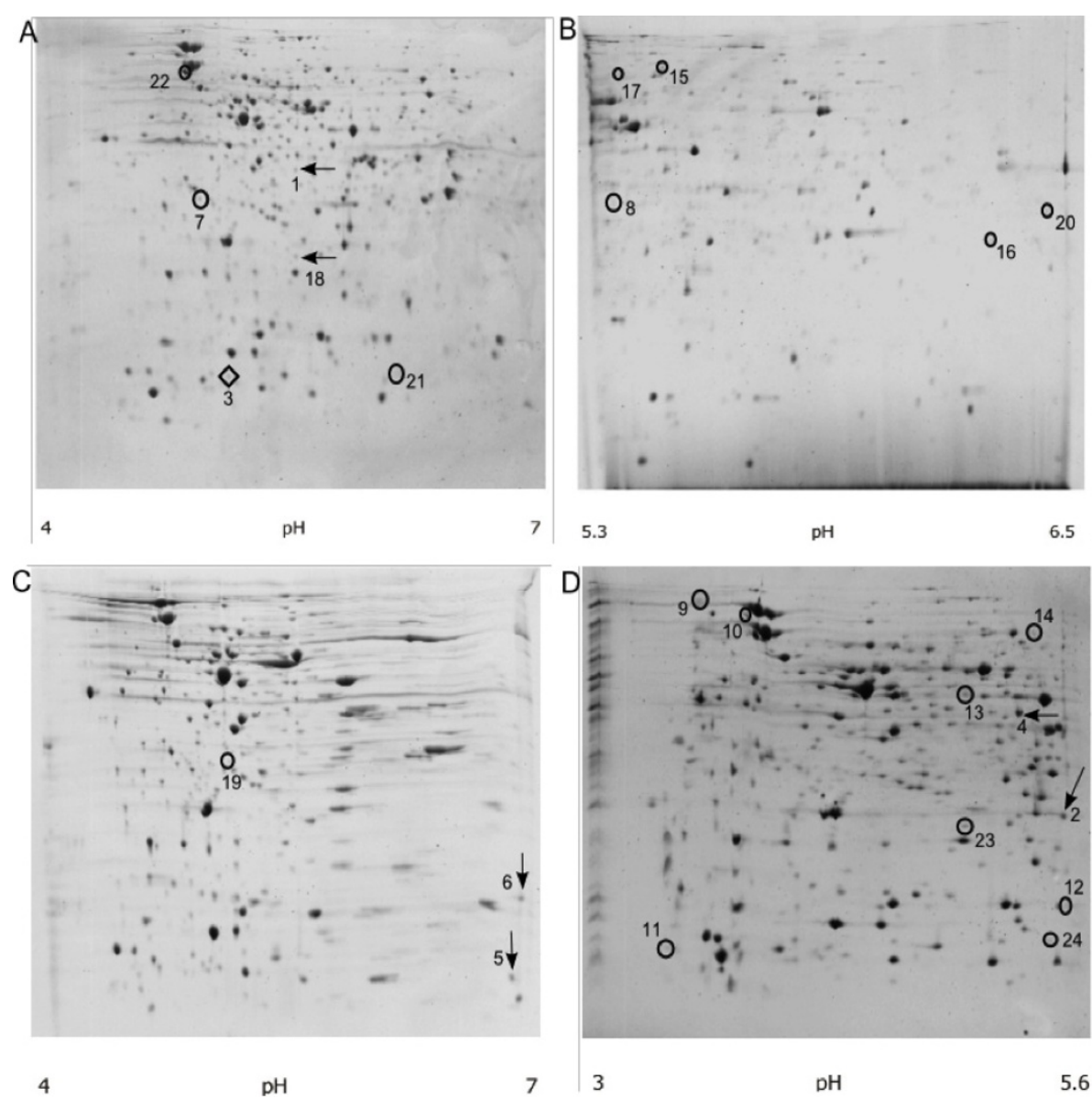

Figure 2 2D-PAGE images of total cell protein from MC1061/\$24 $\mathbf{B}::$ Kan. IEF on pH range 4-7 (A, C), 5.3-6.5 (B) and 3-5.6 (D). Arrows represent proteins identified as phage encoded; circles represent proteins identified as encoded by $E$. coli, but not present on corresponding naïve MC1061 gels (data not shown).

subset of the population undergoing spontaneous induction events. A strategy involving qPCR was developed to provide this important information, and a variety of genes were chosen as controls for this study (Additional file 1: Table S1, Figure 1). Calibration curves for quantitation and comparison of the qRT-PCR data were produced for every set of primers used; $R^{2}$ values from linear regression analyses of these standards ranged from 0.990 to 0.999 with slopes ranging between -3.72 and -3.10 (Additional file 1: Table S1).

The data from the qPCR assay were analysed by comparing the shape of the expression data for any given gene from a lysogen culture throughout the prophage induction process where time 0 is the point of norfloxacin (inducer) addition (Figure 3). Lysogen-restricted gene expression should be negatively affected after induction (Figure 3A, CI), and if expression is actually linked to the small proportion of cells undergoing spontaneous induction, then the expression levels should rise during the induction process. This is indeed the case as expected for Q, Cro, Capsid \& Terminase, which display a significant increase after 50 min of recovery, Figure 3; Additional file 2: Table S2).

Four genes identified by 2D-PAGE, P1, P4, P5 and P6, visibly follow the same expression pattern as the genes expressed during the lytic cycle and accordingly the increase in gene copy number is significant (p-value < 0.05 ) after 50 or $60 \mathrm{~min}$ of recovery from exposure to norfloxacin (Figure 3; Additional file 2: Table S2). P3 and P2 appear to have a similar pattern to $c I$, i.e. their levels of expression in the lysogen are higher than the levels after induction; however the ANOVA analysis did not identify these differences as significant, probably due to the high variability amongst the replicates. Of the five CDS identified by CMAT, which were subsequently selected for expression analysis based upon either their putative function or location within the phage genome, four had expression patterns linked to the lytic cycle. CM18 was shown by qPCR to be strongly expressed in lysogen cultures, but when the cells are induced, high 
Table 2 Protein identities according to the MASCOT database

\begin{tabular}{|c|c|c|c|c|c|c|c|c|c|}
\hline$\overline{P \#}$ & Gene name & Access No. & $\begin{array}{l}\mathrm{pl} / \\
\mathrm{MW} \\
(\mathrm{Da})\end{array}$ & Description & $\begin{array}{c}\text { Sequence }^{\mathrm{a}} \\
\text { Coverage } \\
(\%)\end{array}$ & $\begin{array}{l}\text { MASCOT }^{\mathbf{b}} \\
\text { Score }\end{array}$ & $\begin{array}{c}\text { Peptides }^{c} \\
\text { matches }\end{array}$ & $\begin{array}{c}\text { Estimated } \\
\mathrm{pl} / \mathrm{MW}(\mathrm{Da})\end{array}$ & $\begin{array}{c}\text { MASCOT } \\
\text { Database } \\
\text { Identified in }\end{array}$ \\
\hline 1 & P1 & & $\begin{array}{c}5.28 / \\
33860\end{array}$ & $\begin{array}{l}\text { Identical to hypothetical } \\
\text { protein p78 from } 933 \mathrm{~W}^{\mathrm{d}}\end{array}$ & 32 & $63^{*}$ & 6 & $5.50 / 40000$ & 1 \\
\hline 2 & P2 & & $\begin{array}{c}5.27 / \\
17096\end{array}$ & $\begin{array}{c}\text { Similar to hypothetical protein } \\
\text { p23 from } 933 \mathrm{~W}\end{array}$ & 42 & 39 & 5 & $5.00 / 15000$ & 1 \\
\hline 3 & P3 & & $\begin{array}{c}5.09 / \\
13472\end{array}$ & $\begin{array}{c}\text { Similar to hypothetical protein } \\
\text { p24 from } 933 \mathrm{~W}\end{array}$ & 33 & 55 & 3 & $5.6 / 8000$ & 1 \\
\hline 4 & P4 & & $\begin{array}{l}5.14 / \\
25800\end{array}$ & Identical to exo of $933 \mathrm{~W}$ & 29 & 52 & 5 & $5.5 / 40000$ & 1 \\
\hline 5 & P5 & & $\begin{array}{l}5.29 / \\
7336\end{array}$ & Not known homologue & 83 & 41 & 2 & $7.00 / 7000$ & 1 \\
\hline 6 & P6 & & $\begin{array}{c}5.22 / \\
13628\end{array}$ & $\begin{array}{l}\text { Identical to hypothetical } \\
\text { protein Stx2lp064 }\end{array}$ & 38 & 30 & 4 & $7.00 / 10000$ & 1 \\
\hline 7 & $\operatorname{nanA2}$ & Q6KD26 & $\begin{array}{c}5.77 / \\
34077\end{array}$ & $\mathrm{~N}$-acetylneuraminate lyse 2 & 21 & 47 & 4 & $5.3 / 35000$ & 2 \\
\hline 8 & $\operatorname{gad} B$ & CAQ31981 & $\begin{array}{c}5.29 / \\
52634\end{array}$ & Glutamate decarboxylase beta & 23 & 57 & 7 & $5.3 / 35000$ & 2 \\
\hline 9 & $\operatorname{sod} B$ & P0AGD5 & $\begin{array}{l}5.58 / \\
21121\end{array}$ & Superoxide dismutase [Fe] & 40 & 53 & 6 & $4.00 / 100000$ & 2 \\
\hline 10 & napA & AAC75266 & $\begin{array}{l}8.23 / \\
92983\end{array}$ & Nitrate reductase & 14 & 49 & 7 & $5.5 / 100000$ & 2 \\
\hline 11 & tig & AAA62791 & $\begin{array}{l}4.73 / \\
47994\end{array}$ & Trigger factor & 24 & $58^{*}$ & 7 & $3.5 / 6000$ & 2 \\
\hline 12 & UT189_C3021 & Q1R837 & $\begin{array}{l}4.70 / \\
6971\end{array}$ & Hypothetical protein & 70 & 42 & 2 & $5.5 / 7000$ & 2 \\
\hline 13 & $2 \mathrm{FPKA}$ & ZP_04873224 & $\begin{array}{l}5.24 / \\
32497\end{array}$ & 6-phosphofructokinase & 23 & 46 & 5 & $5.3 / 50000$ & 2 \\
\hline 14 & $g c p E$ & S23058 & $\begin{array}{c}5.87 / \\
40658\end{array}$ & $\begin{array}{l}\text { 1-hydroxy-2-methyl-2-(E)- } \\
\text { butenyl 4-diphosphate } \\
\text { synthase }\end{array}$ & 16 & 38 & 4 & $5.5 / 80000$ & 2 \\
\hline 15 & aceE & POAFG9 & $\begin{array}{l}5.46 / \\
99475\end{array}$ & $\begin{array}{c}\text { Pyruvate dehydrogenase E1 } \\
\text { component }\end{array}$ & 10 & $60^{*}$ & 7 & $5.4 / 100000$ & 2 \\
\hline 16 & $b f p k$ & Q9S141 & $\begin{array}{c}7.63 / \\
18294\end{array}$ & BfpK & 54 & 49 & 3 & $6.4 / 25000$ & 2 \\
\hline 17 & $y c h N$ & POAB53 & $\begin{array}{c}5.02 / \\
12685\end{array}$ & $y c h N$ & 46 & 38 & 2 & $5.3 / 100000$ & 2 \\
\hline 18 & UT189_C1147 & Q1RDD & $\begin{array}{c}5.57 / \\
24945\end{array}$ & Hypothetical protein & 15 & 38 & 4 & $5.7 / 30000$ & 2 \\
\hline 19 & ompC & Q9RH85 & $\begin{array}{l}4.55 / \\
40474\end{array}$ & Outer membrane protein & 18 & 44 & 4 & $5.5 / 40000$ & 2 \\
\hline 20 & ECs1247 & G90784 & $\begin{array}{l}4.74 / \\
25144\end{array}$ & Hypothetical protein & 26 & 39 & 5 & $6.5 / 35000$ & 2 \\
\hline 21 & UT189_C2748 & Q1R8V6 & $\begin{array}{l}10.19 / \\
10724\end{array}$ & Hypothetical protein & 44 & 50 & 4 & $6.4 / 8000$ & 2 \\
\hline 22 & nirB & E86001 & $\begin{array}{l}5.79 / \\
93112\end{array}$ & $\begin{array}{l}\text { Nitrate reductase }(\mathrm{NAD}(\mathrm{P}) \mathrm{H}) \\
\text { Subunit }\end{array}$ & 10 & 53 & 8 & $5.3 / 100000$ & 2 \\
\hline 23 & yagP & CAQ30761 & $\begin{array}{l}5.65 / \\
15401\end{array}$ & yagP protein & 36 & 43 & 3 & $5.3 / 10000$ & 2 \\
\hline 24 & rhsF & Q47284 & $\begin{array}{c}5.69 / \\
23342\end{array}$ & RhsF & 18 & 42 & 4 & $5.69 / 8000$ & 2 \\
\hline
\end{tabular}

Table represents matches to E. coli proteins in the MASCOT database and matches to $Ф 24_{B}$ proteins in the University of Liverpool local MASCOT database

a percentage of sequence of the matched protein that is covered by the experimental MS.

${ }^{b}$ logarithm of the probability that the match between the experimental data and a protein sequence in the database is a random event.

c number of peptides that match the protein in the database

d $933 \mathrm{~W}$ is an Stx2 phage described by Plunkett et al. [16].

e Stx2 is an Stx2 phage described by Sato et al. [20].

*represents significant matches ( $p$-value $<0.05$ )

1 University of Liverpool local MASCOT database; 2 general MASCOT database 


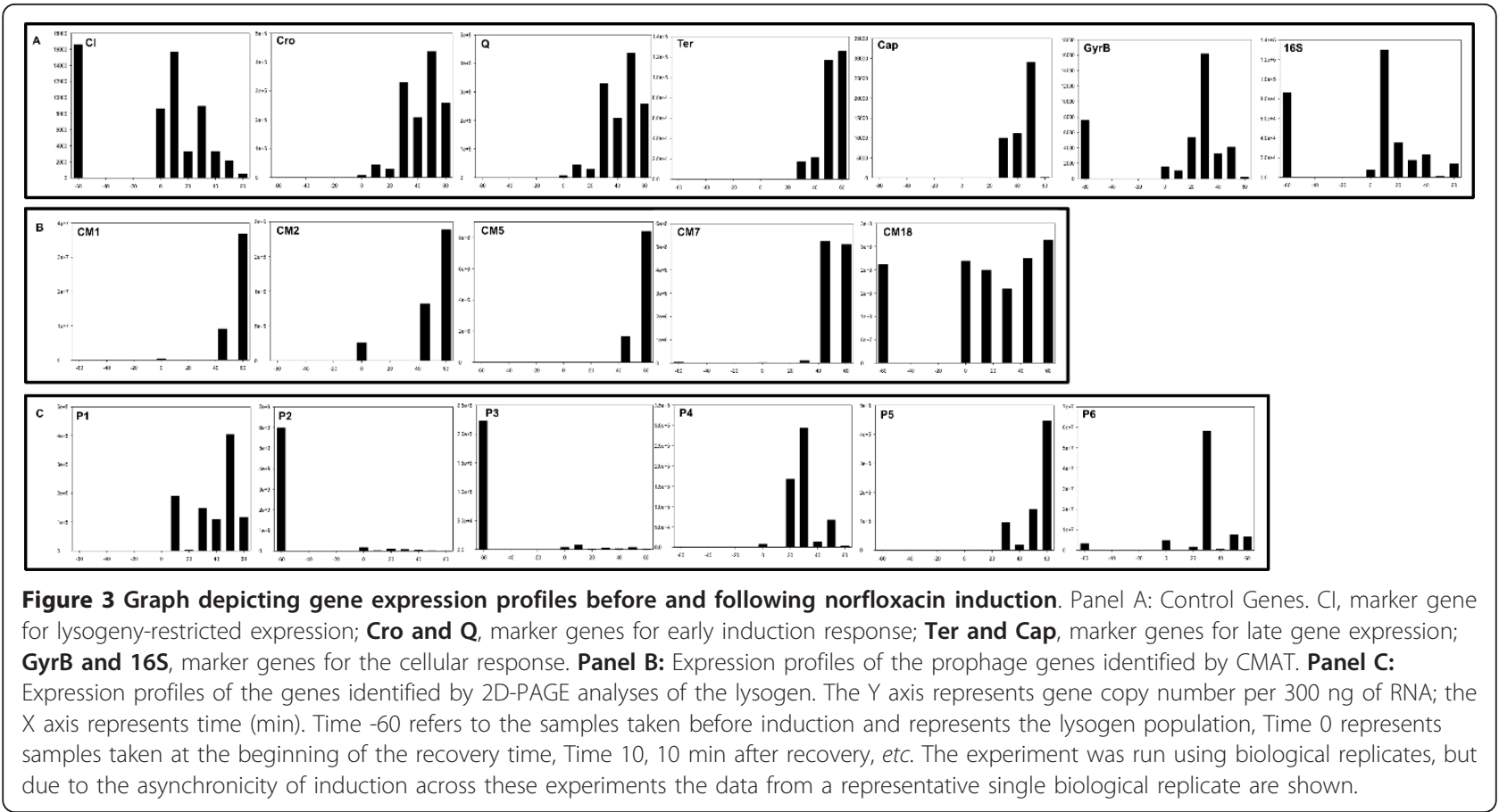

expression levels are maintained, suggesting that expression of this gene has been uncoupled from the phage regulatory circuits. The outcome of one-way ANOVA analysis to determine the impact of prophage induction on gene expression was found to be significant in 11 cases (p-value < 0.05): cI, cro, terminase, capsid, Q, CM1, CM2, CM5, CM7, P1 and P5. The other 7 genes studied did not present significant changes in expression: P2, P3, P4, P6, CM18, 16S, and gyraseB. The full set of $\mathrm{p}$-values for the data in Figure 3 are presented in Additional file 2: Table S2.

\section{Discussion}

Temperate phages, maintained as prophages in their lysogens, have been the subject of speculation concerning their benefit to the host: selective advantage, increased virulence, and other traits with varying degrees of direct and/or indirect impact on the host have been identified [11,21-27]. The challenge in this area has been how to identify phage-encoded genes that directly affect their lysogen, because many/most phage genes are annotated as encoding hypothetical proteins. In addition, there will always be a small background population undergoing spontaneous induction in the absence of discernible stimuli [19], potentially confounding the identification of lysogen-restricted prophage gene expression. In a specific E. coli lysogen of Stx2phage $933 \mathrm{~W}$, a phage very closely related to $\Phi 24_{\mathrm{B}}$, the spontaneous induction rate was calculated as $0.014 \%$ [28], which means that in a lysogen culture fourteen cells per 100,000 are undergoing prophage induction. Other recent work was demonstrated that various induction agents and growth conditions differentially effects induction in a prophage-dependent manner [29]. Assuming a burst size similar to that of bacteriophage Lambda $\left(170 \pm 10\right.$ virions cell $\left.{ }^{-1}\right)$ [27], a significant amount of phage structural protein production can occur in an uninduced lysogen culture.

In order to mitigate this effect, the growth phase at which the ratio of lysogens to free phage was high (two to three hours post inoculation) was targeted. However, the cell density at this point was very low and 5-6 hours was chosen as the standardised incubation time as a compromise. In this study, 26 genes from the bacteriophage $\Phi 24_{\mathrm{B}}$ were identified by either CMAT or 2DPAGE as being expressed in E. coli lysogen culture. No genes were identified by both CMAT and 2D-PAGE methods, perhaps due in part to the low absolute number of $\Phi 24_{\mathrm{B}}$ genes identified by the latter approach. However, the level of redundancy in the genes identified by the CMAT clones was lower than expected, given the number of clones screened and the calculated phage genome coverage; however, putative positive clones were selected conservatively in an attempt to limit the number of false positives. Additionally, CMAT-based identification may also introduce bias into library screening due to differences in protein immunogenicity and antigenicity. It is important to note that the best characterised lysogen-restricted gene, $c I$ (encoding lambdoid phage repressor), was not identified using either CMAT 
or 2D-PAGE, indicating that this study was not exhaustive. Nevertheless, the paucity of information on lysogen-restricted gene expression is such that these data represent a significant step forward in our understanding of phage/host interactions and lysogen biology.

Of the 26 phage genes identified in this study, Tsp, encoding the characterised tail spike protein of $\Phi 24_{B}$ $[30,31]$ was a known structural protein and therefore not expected to be expressed by a stable lysogen (Tables 1 \&3), while the expression profiles of the other 25 proteins were unknown. Therefore the resulting challenge was to identify the fraction of the culture (lysogens or cells undergoing lysis) that were responsible for expression of these 26 phage genes as well as determining testable hypotheses to assign function to the identified gene products. Five genes identified during the CMAT screening were chosen for gene expression profiling due to their genome location, potential function or degree of conservation across a range of phages (Table 3 ). The CDS CM18 encodes a Lom orthologue, which was expected to be expressed in the lysogen as the lambda lom gene is associated with the alteration of the lysogen's pathogenic profile after location of Lom in the outer membrane [32-34]. However, expression of lom in the $\Phi 24_{\mathrm{B}}$ lysogen unexpectedly appears to be uncoupled from the phage regulatory pathways, because it is expressed at similar levels in an infected cell regardless of whether that cell exists as a stable lysogen or is undergoing prophage induction. The CDS CM2 encodes a putative Dam methyltransferase. Bacterial-encoded Dam methyltransferase has been shown to be essential for maintenance of lysogeny in $E$. coli infected with Stx-phage $933 \mathrm{~W}$ [35]. The expression pattern of the $\Phi 24_{\mathrm{B}}$-encoded Dam methyltransferase could indicate that it is fulfilling a similar role, or supplementing the function of the host-encoded Dam methylase in lysogens infected with this phage. The functions of CM5 and CM7 are unknown. CM7 is an ORF of $8 \mathrm{~kb}$, and as the amount of DNA that can be packaged by a phage is limited, such a large gene is likely to be conserved only if it confers an advantage to the phage or its lysogen; it may be significant that this large gene is associated with several other phages (Table 3). CM5 is a small CDS located on the complementary strand to the one encoding $\mathrm{CM} 7$, in a region with few other CDS, though it is directly upstream of another CMAT-identified CDS, CM6. The data (Figure 3 ) indicate that the expression of these 3 genes is linked to prophage induction, a surprising outcome as CM7 does not appear to be a phage structural gene, has been indicated by bioinformatic analyses (data not shown) to be a probable outer membrane protein, and is downstream of CM18, whose regulation is uncoupled from expression of the late genes.
The qPCR expression profile for the phage genes identified as being expressed in the lysogen by 2D-PAGE, P1, P2, P3, P4, P5 and P6, indicated that only the expression of P2 and P3 were restricted to lysogen cultures with a stable prophage. The genes for both P2 and P3 lie downstream of the $c I$ gene. However, their expression levels are one and five orders of magnitude greater, respectively, than the expression levels of $c I$, the lambdoid phage repressor gene. It is known that in Lambda phage, the $c I$ gene transcript is leaderless, possessing no ribosome binding site for initiation of translation, with transcription and translation beginning at the AUG start codon [36]. If this causes the 5' end of the transcript to be less stable and more easily subject to degradation, the higher level of P3 transcript could simply be due to possession of a longer half life than those genes at the 5' end of the transcript.

The genes encoding P2 and P3 are conserved in many other phages (Table 3 ). They have no bioinformatically identifiable promoters of their own, so are likely to be driven by $p R M$ or $p R E$ like $c I$ (see [37] for a cogent review of the related lambda phage), but differences in the levels of transcription between these 3 genes implies that there is still more to discover about the right operator region of this phage. The proteins P1, P4, P5 and P6 all exhibit gene expression profiles that suggest they are expressed following prophage induction. These genes are scattered across the phage genome (Figure 1) and are shared by various phages (Table 3 ). The protein P4 appears to be part of the lambda Red recombinase system [38-40] and the data presented here suggest that this is most active upon prophage induction. This could be relevant to the mechanisms that underpin diversification, evolution and production of new phages by lysogens carrying an inducible prophage along with one or more inducible or remnant prophages $[11,41,42]$. The proteins P1, P5 and P6 are scattered across the genome on the strand typically associated with expression of genes linked to lysogenic infection (e.g. cIII, $N, c I$ ). Two genes encoding proteins P1, P5 and P6 are found in other phages, but have no known function.

In summary, genome sequencing of prophages and bacteriophages has identified that these viral elements encode higher numbers of hypothetical genes than those to which we can currently assign a function. These genes are often conserved across many bacteriophages, but do not appear to encode structural proteins. For these genes to remain present in the phage genome, especially considering the fluidity of the genetic composition of lambdoid phages [43], they must surely provide an important function in either the phage life cycle or that of the lysogen itself. In attempting to identify prophage genes whose expression was restricted to the stable prophage state, our goal was to identify prophage 
Table 3 Distribution of the proteins identified by CMAT and 2D-PAGE across phage genomes

\begin{tabular}{|c|c|c|c|c|}
\hline Gene & Other Stx phages carrying the proteins in the study (identity) & $\begin{array}{c}\text { Accession } \\
\text { number }\end{array}$ & Other phages & $\begin{array}{c}\text { Accession } \\
\text { number }\end{array}$ \\
\hline \multirow[t]{7}{*}{ CM1 } & Stx2 converting phage II (99\%) & YP_003828920.1 & & \\
\hline & phage VT2-Sakai (99\%) & NP_050557.1 & & \\
\hline & phage 933 W (99\%) & NP_049519.1 & & \\
\hline & Stx1 converting phage (99\%) & YP_003848832 & & \\
\hline & phage BP-933 W (99\%) & YP_003848832.1 & & \\
\hline & phage VT2phi_272 (99\%) & ADU03741.1 & & \\
\hline & phage Min27(100\%) & ADU03741 & & \\
\hline \multirow[t]{14}{*}{ CM2 } & Stx2 converting phage II (100\%) & BAC78116 & & \\
\hline & phage VT2-Sakai (100\%) & NP_050531.1 & & \\
\hline & phage Min27 (100\%) & YP_001648926 & & \\
\hline & phage HK97 (99\%) & AAF31137 & & \\
\hline & phage Lahn2 (99\%) & CAJ26400 & & \\
\hline & phage Lahn3 (98\%) & CAC95062.1 & & \\
\hline & phage 2851 (99\%) & CAQ82016 & & \\
\hline & phage CP-1639(99\%) & CAC83142 & & \\
\hline & prophage CP-933 V(99\%) & AAG57233 & & \\
\hline & Phage Nil2 (99\%)(99\%) & CAC95095 & & \\
\hline & Stx1 converting phage (99\%) & YP_003848889.1 & & \\
\hline & Phage CP-1639 (99\%) & CAC83142.1 & & \\
\hline & Phage YYZ-2088 (99\%) & YP_002274170.1 & & \\
\hline & Stx2-converting phage 1717 (99\%) & YP_002274244.1 & & \\
\hline \multirow[t]{6}{*}{ CM5 } & phage Min27 (100\%) & YP_001648966.1 & & \\
\hline & Stx2 converting phage $\|(100 \%)$ & YP_00388933.1 & & \\
\hline & Stx2 converting phage I(100\%) & NP_612929.1 & & \\
\hline & phage VT2-Sakai (100\%) & NP_050570.1 & & \\
\hline & phage 933 W (100\%) & NP_049532.1 & & \\
\hline & phage VT2phi_272 (100\%) & ADU03756 & & \\
\hline \multirow[t]{9}{*}{ CM7 } & phage VT2-Sakai (99\%) & NP_050570 & & \\
\hline & Stx1 converting phage (99\%) & BAC77866.1 & & \\
\hline & Phage VT2phi_272 (97\%) & ADU03756.1 & & \\
\hline & Phage 933 W (97\%) & NP_049532.1 & & \\
\hline & Stx2 converting phage I (97\%) & NP_612929.1 & & \\
\hline & Stx2 converting phage $\|(97 \%)$ & BAC78032.1 & & \\
\hline & Phage BP-933 W (97\%) & AAG55616.1 & & \\
\hline & Stx2 converting phage 86 (91\%) & YP_794082.1 & & \\
\hline & Phage Min27 (97\%) & YP_001648966.1 & & \\
\hline \multirow[t]{8}{*}{ CM18 } & phage VT2-Sakai (100\%) & NP_050564.1 & & \\
\hline & Stx 1 converting phage (100\%) & YP_003848839.1 & & \\
\hline & Phage 933 W (100\%) & NP_049526.1 & & \\
\hline & Stx2 converting phage I (100\%) & ZP_02785836.1 & & \\
\hline & Stx2 converting phage II (100\%) & YP_003828926.1 & & \\
\hline & Phage BP-933 W (100\%) & NP_286999.1 & & \\
\hline & Stx2 converting phage 86 (97\%) & YP_794076.1 & & \\
\hline & Phage Min27 (100\%) & YP_001648959.1 & & \\
\hline \multirow[t]{6}{*}{ P1 } & Stx2 converting phage II (99\%) & YP_003828937.1 & Phage phiV10 (78\%) & YP_512303.1 \\
\hline & Stx2 converting phage I (99\%) & NP_612952.1 & & \\
\hline & Phage 933 W (99\%) & NP_049538.1 & & \\
\hline & Phage BP-933 W (99\%) & AAG55619.1 & & \\
\hline & phage VT2-Sakai (99\%) & NP_050575.1 & & \\
\hline & Phage Min27 (96\%) & YP_001648901.1 & & \\
\hline
\end{tabular}


Table 3 Distribution of the proteins identified by CMAT and 2D-PAGE across phage genomes (Continued)

\begin{tabular}{|c|c|c|c|c|}
\hline & Stx2-converting phage $86(96 \%)$ & YP_794094.1 & & \\
\hline & Phage BP-4795 (96\%) & YP_001449244.1 & & \\
\hline & phage CP-1639 (74\%) & CAC83133.1 & & \\
\hline \multirow[t]{5}{*}{ P2 } & Stx2 converting phage I (100\%) & NP_612997.1 & Salmonella enteric & YP_002455860.1 \\
\hline & Phage 933 W (100\%) & NP_049484.1 & bacteriophage SE1 (86\%) & \\
\hline & Phage BP-933 W (100\%) & AAG55573.1 & Salmonella phage ST160 (86\%) & YP_004123782.1 \\
\hline & Phage Min27 (100\%) & ABY49878.1 & & \\
\hline & Stx2-converting phage 86 (100\%) & YP_794109.1 & & \\
\hline \multirow[t]{5}{*}{ P3 } & Stx2 converting phage I (100\%) & NP_612995.1 & & \\
\hline & Phage 933 W (100\%) & NP_049483.1 & & \\
\hline & Stx2-converting phage 86 (100\%) & YP_794108.1 & & \\
\hline & Phage Min27 (100\%) & YP_001648915.1 & & \\
\hline & Phage BP-933 W (100\%) & AAG55572.1 & & \\
\hline \multirow[t]{10}{*}{ P4 } & Phage 933 W (100\%) & NP_049473.1 & Phage lambda (98\%) & NP_040616.1 \\
\hline & Phage BP-933 W (100\%) & NP_286952.1 & & \\
\hline & Prophage CP-933 V (100\%) & NP_288695.1 & & \\
\hline & Stx2 converting phage I (100\%) & NP_612980.1 & & \\
\hline & Phage VT1-Sakai (100\%) & BAB19617.1 & & \\
\hline & Phage YYZ-2008 (99\%) & YP_002274150.1 & & \\
\hline & Stx2-converting phage 1717 (98\%) & YP_002274221.1 & & \\
\hline & prophage CP-933 K (98\%) & YP_003500773.1 & & \\
\hline & phage BP-4795 (98\%) & YP_001449249.1 & & \\
\hline & phage Min27 (99\%) & YP_001648905.1 & & \\
\hline \multirow[t]{6}{*}{ P5 } & Stx2 converting phage I (100\%) & NP_613032.1 & & \\
\hline & Phage 933 W (100\%) & NP_049503.1 & & \\
\hline & Stx2 converting phage II (100\%) & BAC78139.1 & & \\
\hline & Stx2-converting phage 1717 (98\%) & YP_002274255.1 & & \\
\hline & phage 2851 (98\%) & CAE53952.1 & & \\
\hline & Phage BP-4795 (97\%) & YP_0014419282.1 & & \\
\hline \multirow[t]{7}{*}{ P6 } & Stx2 converting phage I (99\%) & NP_612943.1 & & \\
\hline & Stx2 converting phage II (99\%) & BAC78046.1 & & \\
\hline & phage VT2phi_272 (99\%) & ADU03756.1 & & \\
\hline & phage Min27 (99\%) & YP_001648966.1 & & \\
\hline & phage VT2-Sakai (99\%) & NP_050570.1 & & \\
\hline & Stx1 converting phage (99\%) & BAC77866.1 & & \\
\hline & Stx2-converting phage 86 (96\%) & BAF34067.1 & & \\
\hline
\end{tabular}

genes that were candidates for influencing the fitness of the bacterial host. However, the study was hampered by the fact that lysogen-restricted gene expression can be at very low levels, and phage genes associated with phage replication are expressed at very high levels.

\section{Conclusions}

Two different experimental strategies were employed to identify prophage genes expressed by their lysogen, and it is interesting to note that lysogen-specific antibody recognition of a peptide expression library and differential 2D-PAGE with subsequent protein identification by peptide mass spectrometry, did not identify the same genes or proteins. The failure of both to identify expression of the $c I$ gene encoding the phage repressor was shown by RT-qPCR to be due to the very low expression levels peculiar to this phage gene (Figure 4); the CI protein is also very susceptible to autocatalysis and therefore elusive. Both CMAT and 2D PAGE identified some phage genes that were associated with lytic induction, and the qPCR strategy was useful for discriminating low level expression in stable lysogens from high-level gene expression in the minority of lysogens that were undergoing spontaneous induction. Improving our understanding of the STEC disease process is ever more urgent in light of the recent emergence of a new Shiga-toxin producing E. coli pathotype [44], and determining the function and expression patterns of the 
genes in Stx phage genomes is very important in that context.

\section{Methods}

\section{Bacterial strains and culture}

The E. coli K-12 strain, MC1061, was used as the bacterial host for the production of lysogens. MC1061 $\left(\Phi 24_{\mathrm{B}}\right)$ refers to the $\Phi 24_{\mathrm{B}}$ lysogen of MC1061; naïve MC1061 refers to cells that have not been infected by $\Phi 24_{\mathrm{B}}$. E. coli K-12 strain DM1187 was used as the indicator host strain in plaque assay experiments [18]. BL21-AI cells (Invitrogen, Paisley, U.K.) were used as the expression host for genetic constructs. Bacterial strains, plasmids and phages used in this study are listed in Table 4.

All cultures, unless otherwise stated, were propagated from an overnight $(\sim 16 \mathrm{~h})$ starter culture $(0.5 \% \mathrm{v} / \mathrm{v}$ inoculum) in Luria Bertani (LB) broth (Merck KGaA, Darmstadt, Germany) containing $0.01 \mathrm{M} \mathrm{CaCl}_{2}$, incubated at $37^{\circ} \mathrm{C}$ with shaking at 200 r.p.m. Lysogen cultures were grown in the presence of kanamycin (Kan, 50 $\mu \mathrm{g} \mathrm{ml}^{-1}$ ). Induction of protein expression in BL21-AI cells took place in BHI broth with $0.2 \%$ arabinose and 1 mM IPTG.

\section{Induction of phage lysogens}

Cultures of MC1061 $\left(\Phi 24_{\mathrm{B}}\right)$ cells were incubated with norfloxacin $\left(1 \mu \mathrm{g} \mathrm{mL} L^{-1}\right)$ for $1 \mathrm{~h}$ at $37^{\circ} \mathrm{C}$ with shaking at 200 r.p.m. Cultures were then diluted 1:10 in fresh LB and the bacteria allowed to recover from the growth inhibitory effects of the antibiotic for $1 \mathrm{~h}$ at $37^{\circ} \mathrm{C}$ (the recovery period), with shaking at 200 r.p.m.

\section{Antisera production for use in CMAT}

A $2 \mathrm{~L}$ culture of MC1061(Ф24B) was propagated for 6 hours. The cells were pelleted and resuspended in $1 \mathrm{ml}$ of retained supernatant plus $1 \mathrm{ml}$ of LB broth. Protease inhibitors $(20 \mu \mathrm{L})$ (Roche Complete Mini EDTA Free protease inhibitor cocktail tablets, Bath, U.K.) and $10 \mu \mathrm{L}$ of lysis buffer (7 M urea, $2 \mathrm{M}$ thiourea, 2\% CHAPS, $1 \%$ DTT, Roche Complete Mini EDTA-free protease inhibitor cocktail tablets) were added to each. The samples were sonicated at $15-18 \mu$ for $6 \times 10 \mathrm{~s}$ bursts. Absolute methanol $(1.5 \mathrm{ml})$ was added, and the samples were incubated at $-20^{\circ} \mathrm{C}$ for $60 \mathrm{~min}$. Protein was harvested by centrifugation at $16,000 \mathrm{~g}$ for $5 \mathrm{~min}$, and the resultant protein pellets were air-dried and suspended in $0.5 \mathrm{ml}$ phosphate buffered saline (PBS). The samples were pooled; the protein content was measured by Bradford Assay [46] and adjusted to $1 \mathrm{mg} \mathrm{ml}^{-1}$. A total of $4 \mathrm{mg}$ of the lysogen protein was sent to Eurogentec (Seraing, Belgium) for antisera production in rabbits, using the Ribi adjuvant system. Two rabbits were immunised with the protein sample on days $0,14,28$ and 56 of the program. Bleeds were carried out on days 0 (pre-immune sera), 38, 66 and 87 (final bleed). Pre-immune sera from the two rabbits used were received and tested for crossreactivity by western blot analysis.

CMAT was carried out as per instructions from the license holder, Oragenics Inc., FL., U.S.A. [17,47], with the exception that BL21-AI was used as the expression strain for the phage library. The recommended expression host, BL21[DE3], is an E. coli- $\lambda$ lysogen, and therefore an inappropriate strain to use in phage protein expression studies [48]. The expression library was created from $\Phi 24_{\mathrm{B}}:$ Kan DNA. The rabbit antisera were depleted of antibodies reactive to $E$. coli proteins by a series of adsorptions to naïve MC1061 whole cells and cellular lysate, and to BL21-AI + pET30c (empty vector) whole cells and cellular lysate. The depleted antisera were compared to undepleted antisera by western blot. Adsorptions were repeated until no bands were detectable by western blot probing of $6 \mu \mathrm{g}$ of naïve MC1061 proteins.

\section{Peptide expression library construction}

Semi-confluent plaque assay plates [18] were overlaid with $3 \mathrm{ml} \mathrm{SM}$ buffer $(100 \mathrm{mM} \mathrm{NaCl}, 8 \mathrm{mM} \mathrm{MgSO} 4,50$ $\mathrm{mM}$ Tris- $\mathrm{HCl}, \mathrm{pH} 7.5$ ) and incubated at $4^{\circ} \mathrm{C}$ for $16 \mathrm{~h}$, with gentle agitation. The SM buffer and top agar were transferred to separate $50 \mathrm{ml}$ centrifuge tubes that were vortexed with $10 \%(\mathrm{v} / \mathrm{v})$ fresh SM buffer and subjected to centrifugation at $10,000 \mathrm{~g}$ for $10 \mathrm{~min}$. The supernatant was pooled and $30 \mu \mathrm{l}$ of chloroform were added to each $10 \mathrm{ml}$ of buffer. DNase $\left(5 \mu \mathrm{g} \mathrm{ml}^{-1}\right)$ and RNase (1 $\mathrm{mg} \mathrm{ml}^{-1}$ ) were added, and the samples were incubated at $37^{\circ} \mathrm{C}$ for $1 \mathrm{~h}$. PEG $8000(33 \%$ [w/v]) was added, and the samples were incubated on ice for $30 \mathrm{~min}$.

Table 4 Bacterial strains, plasmid and phages used in the study

\begin{tabular}{|c|c|c|}
\hline E.coli strains, plasmids and phages & Relevant Genotype & Reference \\
\hline BL21-AI & F- ompT hsdSB(rB-, mB-) gal dcm (DE3), arabinose inducible T7 RNA polymerase & Invitrogen, Paisley, U.K. \\
\hline MC1061 & $\mathrm{F}^{-} \Delta\left(\right.$ ara-leu)7697 $\Delta\left(\operatorname{codB}\right.$-lacl)3 galK16 $\lambda^{-}$mcrA0 rpsL150(strR) mcrB1 & [18] \\
\hline DM1187 & F- dam-13:: $\operatorname{Tn} 9\left(\mathrm{Cm}^{\mathrm{R}}\right) d \mathrm{~cm}-\mathrm{mcrB}$ hsdR-M + gall ara- lac- thr- leu- $t 5 x R$ & [45] \\
\hline TOP10 & F- mcrA Ф80/acZ $\triangle M 15$ recA ${ }^{+}$ & Invitrogen, Paisley, U.K. \\
\hline pCR ${ }^{\circledR}$-Blunt & $l a c Z \alpha, \operatorname{Kan}^{R}, \operatorname{ccdB}$ & Invitrogen, Paisley, U.K. \\
\hline pET30c & Expression vector with $\mathrm{T} 7$ promoter, $\mathrm{Kan}^{\mathrm{R}}, \mathrm{Tet}^{\mathrm{R}}$, & Novagen, Notts, UK \\
\hline$\Phi 24_{B}$ & Stx2-phage, $\Delta s t \times A_{2}:: a p h 3$ & [14] \\
\hline
\end{tabular}


Precipitated phage particles were harvested by centrifugation for $10 \mathrm{~min}$ at $10,000 \mathrm{~g}$, and the pellets were resuspended in $500 \mu \mathrm{l}$ SM buffer per $30 \mathrm{ml}$ starting volume. Samples were treated with DNase and RNase, as before. Phage DNA was purified by phenol:chloroform:isoamyl alcohol extraction and isopropanol precipitation [49] and resuspended in $100 \mu \mathrm{ldd} \mathrm{H}_{2} \mathrm{O}$. The $\Phi 24_{\mathrm{B}}$ DNA $\left(15 \mu \mathrm{g} \mathrm{ml}^{-1}\right.$ in TE) was fragmented using a HydroShear (GeneMachines, MI, USA), at speed code 6 for 30 cycles, followed by 30 cycles at speed code 2 . DNA of the required size range (300-900 bp) was isolated by gel purification. pET30c plasmid (EMD Biosciences) DNA was digested with EcoR V and dephosphorylated with calf intestinal phosphatase (New England Biolabs) according to the manufacturer's recommendations. The size fractionated $\Phi 24_{\mathrm{B}}$ DNA fragments were cloned into the prepared pET30c DNA (50 ng) vector in a molar ratio of 25:1 (insert to vector). Chemically competent BL21-AI expression host cells (Invitrogen) were transformed with the plasmid DNA according to the manufacturer's recommendations.

\section{Primary screening}

Transformed BL21-AI cells were plated onto LBKan plates and incubated at $37^{\circ} \mathrm{C}(11 \mathrm{~h})$. Nitrocellulose membrane $(0.2 \mu \mathrm{m}$ pore size, BioTraceTM) was laid onto the top of each plate for approximately $1 \mathrm{~min}$. The membranes were transferred colony-side up to LBKan agar plates supplemented with arabinose $(0.2 \%)$ and IPTG $(1 \mathrm{mM})$, and incubated at $37^{\circ} \mathrm{C}$ for $3 \mathrm{~h}$. The master plates were incubated for a further $3-5 \mathrm{~h}$ at $37^{\circ} \mathrm{C}$, until the colonies reached a diameter of 1-2 mm. The membranes were lifted from the agar plates and placed on chloroform-saturated filter paper, colony-side down, for $1 \mathrm{~min}$, after which the chloroform was allowed to evaporate completely. The membranes were then gently agitated in blocking solution (PBS plus 0.5\% Tween 20 and 5\% skimmed milk powder) for $1 \mathrm{~h}$ at ambient temperature, washed in PBST (PBS plus 0.5\% Tween 20; 4 $\times 10 \mathrm{~min}$ ) with gentle agitation and probed with the primary antibodies (depleted antisera) in $10 \mathrm{ml} \mathrm{PBST}$ $(1: 1,250)$ for $16 \mathrm{~h}$ at $4{ }^{\circ} \mathrm{C}$ with gentle agitation. The membranes were then washed four times in PBST and agitated for $1.5 \mathrm{~h}$ in secondary antibody solution (HRP conjugated to goat anti-rabbit IgG [Sigma]) (1:30,000). The membranes were washed four times in PBST, rinsed twice in PBS and washed for $10 \mathrm{~min}$ in PBS, under gentle agitation. Enhanced chemiluminescent (ECL) reagent was used to develop the membranes and the chemiluminescence was visualised by exposure of Roche Lumi-Film Chemiluminescent Detection Film to the membranes. Putative positive clones were identified on the master plates and each one was transferred to fresh LBKan agar.

\section{PCR verification of insert}

For verification of the presence of cloned DNA, putative positive colonies were used as the template source for a colony PCR and the T7 promoter and T7 terminator primers (Novagen, Notts, U.K.). Thermal cycling conditions using Taq polymerase comprised an initial denaturation of $5 \mathrm{~min}$ at $94^{\circ} \mathrm{C}, 35$ cycles of denaturation at $94^{\circ} \mathrm{C}$ for $30 \mathrm{~s}$, annealing at $55^{\circ} \mathrm{C}$ for $30 \mathrm{~s}$, extension at $72^{\circ} \mathrm{C}$ for $30 \mathrm{~s} \mathrm{~kb}^{-1}$ product, followed by a final extension at $72^{\circ} \mathrm{C}$ for $7 \mathrm{~min}$.

\section{Secondary screening}

Putative positive colonies were cultured overnight in BHI Kan $(1 \mathrm{ml})$, at $37^{\circ} \mathrm{C}$, without shaking. The cells were harvested by centrifugation at $16,000 \mathrm{~g}$. The supernatant was decanted and the cells resuspended in 201 BHI Kan. Each suspension was spotted in triplicate (1 $\mu \mathrm{l})$ onto duplicate nitrocellulose membranes and placed on a BHI Kan agar plate. The plates and membranes were incubated for $3 \mathrm{~h}$ at $37^{\circ} \mathrm{C}$, the membranes removed and one of the duplicate membranes overlaid onto a LB Kan agar plate supplemented with $0.2 \%$ arabinose and 1 mM IPTG while the other membrane was placed onto a LB Kan agar plate. These were incubated for $3 \mathrm{~h}$ at $37^{\circ}$ C. The membranes were removed from the plates, and placed on chloroform- saturated filter paper for $1 \mathrm{~min}$. Once dry, $1 \mu$ l of the lysogen-specific antiserum was spotted onto the bottom of the membrane, as a positive control. Antibody reactivity was determined as described above for primary screening.

\section{DNA sequencing}

Plasmid DNA was sequenced by GATC Biotech (Konstanz, Germany), using the T7 promoter and terminator primers. Sequences were translated using ExPASY's Translate tool http://www.expasy.ch/tools/\#proteome. The sequences were aligned to the annotated $\Phi 24_{\mathrm{B}}$ genome [GenBank:HM_208303] and CDS in-frame with the expression vector were documented.

\section{qPCR}

Induction of MC1061( $\left(24_{\mathrm{B}}\right)$ cultures was performed as described above. A $1 \mathrm{ml}$ sample was taken before addition of norfloxacin to the cultures, and further $1 \mathrm{ml}$ aliquots removed at 10-15 min intervals throughout the 60 min recovery time. RNA was immediately extracted and DNAse treated with TURBO ${ }^{\mathrm{TM}}$ DNAse (Ambion, TX, USA) according to the manufacturer's instructions. Absence of DNA was verified by qPCR. Each RNA sample (300 ng) was reverse transcribed using random hexamer oligonucleotides (Bioline, London, UK). Specific primers were designed to amplify an approximately 100 bp region of each gene in the study (Additional file 1: Table S1). qPCR was performed using a StepOnePlus ${ }^{\mathrm{TM}}$ 
Real-Time PCR System (Applied Biosystems); each reaction consisted of $1 \mu \mathrm{l}$ of cDNA, $1 \times$ SensiMixPlus SYBR (Quantace, London, U.K.), $200 \mathrm{nM}$ of specific primers in a $25 \mu \mathrm{l}$ reaction. The amplification cycling conditions were: initial denaturation at $95^{\circ} \mathrm{C}$ for $10 \mathrm{~min}$; 39 cycles of denaturation at $95^{\circ} \mathrm{C}$ for $10 \mathrm{~s}$; annealing at $60^{\circ} \mathrm{C}$ for $30 \mathrm{~s}$; extension at $72^{\circ} \mathrm{C}$ for $5 \mathrm{~s}$. A melting curve analysis was performed for each amplification reaction, with a temperature gradient of $0.1^{\circ} \mathrm{C}$ from $55^{\circ} \mathrm{C}$ to $95^{\circ} \mathrm{C}$. Notemplate controls and a calibration curve, consisting of 6 dilutions of the PCR amplicon of each gene cloned into PCR-Blunt vector (Invitrogen, Paisley, U.K.) linearised with Nco I (NEB, Herts, U.K.), were included in every experiment (Additional file 1: Table S1). Statistical analysis was performed using a one-way ANOVA comparing gene copy numbers at different time points in each experiment to test the hypothesis that there is no variation in gene copy number during the recovery period. A post-hoc Dunnett's test was employed, using the sample corresponding to the lysogen culture $(-60)$ as the reference group, to assess whether or not time points differed from the reference. $\mathrm{P}<0.05$ values were considered to be statistically significant.

\section{Protein extraction for 2D-PAGE}

Cultures of MC1061 and MC1061(Ф24B) were incubated for $6 \mathrm{~h}$ at $37^{\circ} \mathrm{C}$. Cells were harvested and pellets washed in $1 \mathrm{ml}$ of wash solution ( $10 \mathrm{mM}$ Tris- $\mathrm{HCl}, \mathrm{pH}$ 8.0; $1.5 \mathrm{mM}$ $\mathrm{KH}_{2} \mathrm{PO}_{4} ; 68 \mathrm{mM} \mathrm{NaCl} ; 9 \mathrm{mM} \mathrm{NaH} 2 \mathrm{PO}$ ). Cells were resuspended in $1 \mathrm{ml}$ of resuspension buffer $(10 \mathrm{mM}$ Tris$\mathrm{HCl}, \mathrm{pH} 8.0 ; 1.5 \mathrm{mM} \mathrm{MgCl} 2 ; 10 \mathrm{mM} \mathrm{KCl} ; 0.5 \mathrm{mM}$ DTT; $0.1 \%$ SDS; $20 \mu \mathrm{l}$ of protease inhibitor [Roche CompleteMini EDTA Free protease inhibitor cocktail tablets]) and each sample was sonicated for $5 \times 10 \mathrm{~s}$. DNase was added $\left(5 \mu \mathrm{g} \mathrm{ml}^{-1}\right)$ and samples were incubated for $1 \mathrm{~h}$ at $37^{\circ} \mathrm{C}$. Samples were centrifuged for $1 \mathrm{~h}$ at $12,000 \mathrm{~g}$, the supernatant recovered and protein concentration determined using the Bradford Assay. Aliquots (110 $\mu \mathrm{g}$ protein) of the sample were taken and precipitated in 10\% TCA in acetone containing $20 \mathrm{mM}$ DTT for 45 minutes at $-20^{\circ} \mathrm{C}$. Pellets were washed twice in ether.

\section{D-PAGE}

Isoelectric focussing was carried out on $18 \mathrm{~cm}$ IPG strips (pH 4-7,3-5.6 and 5.3-6.5;GE Healthcare), at 3,500 $\mathrm{V}$ for $7 \mathrm{~h}$. Proteins were separated in the second dimension on $1.5 \mathrm{~mm} 4 \%$ stacking/15\% resolving SDS-PAGE gels, for $6.5 \mathrm{~h}$ at $20 \mathrm{~W}$ per gel (up to maximum of 180 W). Proteins were silver stained [50].

\section{In-gel digestion of protein samples}

This was carried out according to the protocol described by Courchesne \& Patterson [51] with the following modifications: protein spots were excised from the gel and destained with $50 \mu \mathrm{l}$ of destaining solution $(30 \mathrm{mM}$ potassium ferricyanide, $100 \mathrm{mM}$ sodium thiosulphate) until the silver stain disappeared; protein digestion proceeded in $25 \mathrm{mM}$ ammonium carbonate/trypsin (5 ng $\left.\mathrm{\mu l}^{-1}\right)$ at $37^{\circ} \mathrm{C}$ for $16 \mathrm{~h}$.

\section{Matrix-assisted laser desorption/ionisation-time-of-flight (MALDI-TOF) mass spectrometry}

Trypsin-digested protein samples were added to an alpha-cyano 4-hydroxycinnamic acid matrix (LaserBioLabs, France) at a concentration of $10 \mathrm{mg} \mathrm{ml}^{-1}$ in $50 \%$ ethanol: $50 \%$ acetonitrile: $0.1 \%$ TFA. Samples were analysed by MALDI-TOF on an ABI Voyager DE Pro (MALDI-TOF). The mass spectra generated were processed using Data Explorer to clean the spectra and isolate monoisotopic peaks (all Applied Biosystems). The Mascot Peptide Mass Fingerprint Database was used to search for homologues.

\section{Additional material}

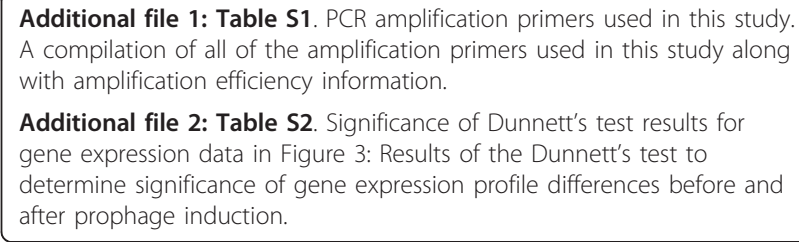

Additional file 1: Table S1. PCR amplification primers used in this study. A compilation of all of the amplification primers used in this study along with amplification efficiency information.

Additional file 2: Table S2. Significance of Dunnett's test results for gene expression data in Figure 3: Results of the Dunnett's test to determine significance of gene expression profile differences before and after prophage induction.

\section{Acknowledgements}

This work was funded by the Biotechnology and Biological Research Council (BBSRC) of the United Kingdom through a Strategic Studentship to HEA and a research grant to HEA and AJM (BB/I013431/1). The authors would also like to acknowledge the experimental support for this work provided by Steven Hooton and Dr. James E. McDonald.

\section{Author details}

'Microbiology Research Group, Institute of Integrative Biology, University of Liverpool, BioSciences Building, Crown Street, Liverpool L69 7ZB, UK. ${ }^{2}$ Program in Molecular Structure \& Function, The Hospital for Sick Children, 555 University Avenue, Toronto, ON M5G 1X8, Canada. ${ }^{3}$ Oragenics, 13700 Progress Blvd, Alachua, FL 32615, USA.

\section{Authors' contributions}

LMR carried out the CMAT analyses and determined the growth and sampling times for the lysogen cultures. MV-G carried out the 2D-PAGE analyses, developed and performed the qRT-PCR assays and produced the figures. MH prepared all DNA samples for CMAT library production. JDH and $\mathrm{MH}$ designed CMAT and were involved in technical critiquing of these experiments. AJM and HEA designed the study and were involved in the interpretation of all data. All authors were involved in the writing and editing of this manuscript including the reading and approval of the final version.

Received: 15 November 2011 Accepted: 22 March 2012 Published: 22 March 2012

\section{References}

1. Ethelberg S, Olsen K, Scheutz F, Jensen C, Schiellerup P, Enberg J, Petersen A, Olesen B, Gerner-Smidt P, Mølbak K: Virulence factors for hemolytic uremic syndrome, Denmark. Emerg Infect Dis 2004, 10:842-847. 
2. Griffin P, Ostroff S, Tauxe R, Greene K, Wells J, Lewis J, Blake P: Illnesses associated with Escherichia coli 0157:H7 infections. A broad clinical spectrum. Ann Intern Med 1988, 109:705-712.

3. Karmali M, Petric M, Lim C, Fleming P, Steele B: Escherichia coli cytotoxin, haemolytic-uraemic syndrome, and haemorrhagic colitis. Lancet 1983, 2:1299-1300

4. Kaper J, Nataro J, Mobley H: Pathogenic Escherichia coli. Nat Rev Microbiol 2004, 2:123-140,

5. Suzuki M, Kondo F, Ito Y, Matsumoto M, Hata M, Oka H, Takahashi M, Sakae K: Identification of a Shiga-toxin type I variant containing an IS1203-like element, from Shiga-toxin producing Escherichia coli 0157: H7. FEMS Microbiol Lett 2004, 234:63-67.

6. Zhang W, Bielaszewska M, Kuczius T, Karch H: Identification, characterization, and distribution of a Shiga toxin 1 gene variant (stx (1c)) in Escherichia coli strains isolated from humans. J Clin Microbiol 2002, 40:1441-1446.

7. O'Loughlin E, Robins-Browne R: Effect of Shiga toxin and Shiga-like toxins on eukaryotic cells. Microbes Infect 2001, 3:493-507.

8. O'Brien A, Lively T, Chang T, Gorbach S: Purification of Shigella dysenteriae 1 (Shiga)-like toxin from Escherichia coli 0157:H7 strain associated with haemorrhagic colitis. Lancet 1983, 2:573.

9. Smith $H$, Green P, Parsell Z: Vero cell toxins in Escherichia coli and related bacteria: transfer by phage and conjugation and toxic action in laboratory animals, chickens and pigs. J Gen Microbiol 1983, 129:3121-3137.

10. Smith HR, Day NP, Scotland SM, Gross RJ, Rowe B: Phage-determined production of vero cytotoxin in strains of Escherichia coli serogroup O157. Lancet 1984, 1:1242-1243.

11. Allison H: Stx-phages: drivers and mediators of the evolution of STEC and STEC-like pathogens. Future Microbiol 2007, 2:165-174.

12. Hayashi T, Makino K, Ohnishi M, Kurokawa K, Ishii K, Yokoyama K, Han CG, Ohtsubo E, Nakayama K, Murata T, et al: Complete genome sequence of enterohemorrhagic Escherichia coli 0157:H7 and genomic comparison with a laboratory strain K-12. DNA Res 2001, 8:11-22.

13. Los JM, Los M, Wegrzyn G: Bacteriophages carrying Shiga toxin genes: genomic variations, detection and potential treatment of pathogenic bacteria. Future Microbiol 2011, 6:909-924.

14. Allison HE, Sergeant MJ, James CE, Saunders JR, Smith DL, Sharp RJ, Marks TS, McCarthy AJ: Immunity profiles of wild-type and recombinant shiga-like toxin-encoding bacteriophages and characterization of novel double lysogens. Infect Immun 2003, 71:3409-3418.

15. Miyamoto H, Nakai W, Yajima N, Fujibayashi A, Higuchi T, Sato K, Matsushiro A: Sequence analysis of Stx2-converting phage VT2-Sa shows a great divergence in early regulation and replication regions. DNA Res 1999, 6:235-240.

16. Plunkett G, Rose DJ, Durfee TJ, Blattner FR: Sequence of Shiga toxin 2 phage 933W from Escherichia coli 0157:H7: Shiga toxin as a phage lategene product. I Bacteriol 1999, 181:1767-1778.

17. Handfield M, Hillman J: In vivo induced antigen technology (IVIAT) and change mediated antigen technology (CMAT). Infect Disord Drug Targets 2006, 6:327-334.

18. James CE, Stanley KN, Allison HE, Flint HJ, Stewart CS, Sharp RJ, Saunders JR, McCarthy AJ: Lytic and lysogenic infection of diverse Escherichia coli and Shigella strains with a verocytotoxigenic bacteriophage. Appl Environ Microbiol 2001, 67:4335-4337.

19. Lwoff A: Lysogeny. Bacteriol Rev 1953, 17:269-337.

20. Sato T, Shimizu T, Watarai M, Kobayashi M, Kano S, Hamabata T, Takeda Y, Yamasaki S: Distinctiveness of the genomic sequence of Shiga toxin 2converting phage isolated from Escherichia coli 0157:H7 Okayama strain as compared to other Shiga toxin 2-converting phages. Gene 2003, 309:35-48.

21. Arraiano CM, Bamford J, Brussow H, Carpousis AJ, Pelicic V, Pfluger K, Polard P, Vogel J: Recent advances in the expression, evolution, and dynamics of prokaryotic genomes. J Bacteriol 2007, 189:6093-6100.

22. Brussow H: Bacteria between protists and phages: from antipredation strategies to the evolution of pathogenicity. Mol Microbiol 2007, 65:583-589.

23. Brussow H, Canchaya C, Hardt WD: Phages and the evolution of bacterial pathogens: from genomic rearrangements to lysogenic conversion. Microbiol Mol Biol Rev 2004, 68:560-602.
24. Mavrodi DV, Loper JE, Paulsen IT, Thomashow LS: Mobile genetic elements in the genome of the beneficial rhizobacterium Pseudomonas fluorescens Pf-5. BMC Microbiol 2009, 9:8.

25. Perkins TT, Kingsley RA, Fookes MC, Gardner PP, James KD, Yu L, Assefa SA, He M, Croucher NJ, Pickard DJ, et al: A strand-specific RNA-Seq analysis of the transcriptome of the typhoid bacillus Salmonella typhi. PLoS Genet 2009, 5:e1000569.

26. Su LK, Lu CP, Wang Y, Cao DM, Sun JH, Yan YX: Lysogenic infection of a Shiga toxin 2-converting bacteriophage changes host gene expression, enhances host acid resistance and motility. Mol Biol (Mosk) 2010, 44:60-73.

27. Wang X, Kim Y, Ma Q, Hong SH, Pokusaeva K, Sturino JM, Wood TK: Cryptic prophages help bacteria cope with adverse environments. Nat Commun 2010, 1:147.

28. Livny J, Friedman D: Characterizing spontaneous induction of Stx encoding phages using a selectable reporter system. Mol Microbiol 2004, 51:1691-1704.

29. Los JM, Los M, Wegrzyn G, Wegrzyn A: Differential efficiency of induction of various lambdoid prophages responsible for production of Shiga toxins in response to different induction agents. Microb Pathog 2009, 47:289-298.

30. Smith DL, James CE, Sergeant MJ, Yaxian Y, Saunders JR, McCarthy AJ, Allison HE: Short-tailed Stx phages exploit the conserved YaeT protein to disseminate Shiga toxin genes among enterobacteria. J Bacteriol 2007, 189:7223-7233.

31. Smith DL, Wareing BM, Fogg PC, Riley LM, Spencer M, Cox MJ, Saunders JR, McCarthy AJ, Allison HE: Multilocus characterization scheme for Shiga toxin-encoding bacteriophages. Appl Environ Microbiol 2007, 73:8032-8040.

32. Barondess JJ, Beckwith J: A bacterial virulence determinant encoded by lysogenic coliphage lambda. Nature 1990, 346:871-874.

33. Reeve JN, Shaw JE: Lambda encodes an outer membrane protein: the lom gene. Mol Gen Genet 1979, 172:243-248.

34. Vica Pacheco S, Garcia Gonzalez O, Paniagua Contreras GL: The lom gene of bacteriophage lambda is involved in Escherichia coli K12 adhesion to human buccal epithelial cells. FEMS Microbiol Lett 1997, 156:129-132.

35. Murphy KC, Ritchie JM, Waldor MK, Lobner-Olesen A, Marinus MG: Dam methyltransferase is required for stable lysogeny of the Shiga toxin (Stx2)-encoding bacteriophage 933W of enterohemorrhagic Escherichia coli O157:H7. J Bacteriol 2008, 190:438-441.

36. Moll I, Grill S, Gualerzi CO, Blasi U: Leaderless mRNAs in bacteria: surprises in ribosomal recruitment and translational control. Mol Microbiol 2002, 43:239-246.

37. Oppenheim AB, Kobiler O, Stavans J, Court DL, Adhya S: Switches in bacteriophage lambda development. Ann Rev Genet 2005, 39:409-429.

38. Lesic B, Rahme LG: Use of the lambda Red recombinase system to rapidly generate mutants in Pseudomonas aeruginosa. BMC Mol Biol 2008, 9:20.

39. Mosberg JA, Lajoie MJ, Church GM: Lambda red recombineering in Escherichia coli occurs through a fully single-stranded intermediate. Genetics 2010, 186:791-799.

40. Muniyappa K, Radding CM: The homologous recombination system of phage lambda. Pairing activities of beta protein. J Biol Chem 1986, 261:7472-7478.

41. Fogg P, Gossage S, Smith D, Saunders J, McCarthy A, Allison H: Identification of multiple integration sites for Stx-phage Phi24B in the Escherichia coli genome, description of a novel integrase and evidence for a functional anti-repressor. Microbiology 2007, 153:4098-4110.

42. Fogg PC, Rigden DJ, Saunders JR, McCarthy AJ, Allison HE: Characterization of the relationship between integrase, excisionase and antirepressor activities associated with a superinfecting Shiga toxin encoding bacteriophage. Nucleic Acids Res 2011, 39:2116-2129.

43. Juhala RJ, Ford ME, Duda RL, Youlton A, Hatfull GF, Hendrix RW: Genomic sequences of bacteriophages HK97 and HK022: pervasive genetic mosaicism in the lambdoid bacteriophages. J Mol Biol 2000, 299:27-51.

44. Rasko DA, Webster DR, Sahl JW, Bashir A, Boisen N, Scheutz F, Paxinos EE, Sebra R, Chin CS, lliopoulos D, et al: Origins of the E. coli strain causing an outbreak of hemolytic-uremic syndrome in Germany. New Eng J Med 2011, 365:709-717.

45. Mount DW: A mutant of Escherichia coli showing constitutive expression of the lysogenic induction and error-prone DNA repair pathways. Proc Natl Acad Sci USA 1977, 74:300-304. 
46. Bradford M: A rapid and sensitive method for the quantitation of microgram quantities of protein utilizing the principle of protein-dye binding. Anal Biochem 1976, 72:248-254

47. Handfield M, Progulske-Fox A, Hillman J: In vivo induced genes in human diseases. Periodontol 2000 2005, 38:123-134.

48. Herold S, Siebert J, Huber A, Schmidt H: Global expression of prophage genes in Escherichia coli 0157:H7 strain EDL933 in response to norfloxacin. Antimicrob Agents Chemother 2005, 49:931-944.

49. Sambrook J, Fritsch EF, Maniatis T: Molecular cloning: a laboratory manual. 2 edition. Cold Spring Harbor, N.Y: Cold Spring Harbor Laboratory; 1989.

50. Yan JX, Wait R, Berkelman T, Harry RA, Westbrook JA, Wheeler CH, Dunn MJ: A modified silver staining protocol for visualization of proteins compatible with matrix-assisted laser desorption/ionization and electrospray ionization-mass spectrometry. Electrophoresis 2000, 21:3666-3672.

51. Courchesne PL, Luethy R, Patterson SD: Comparison of in-gel and onmembrane digestion methods at low to sub-pmol level for subsequent peptide and fragment-ion mass analysis using matrix-assisted laserdesorption/ionization mass spectrometry. Electrophoresis 1997, 18:369-381.

doi:10.1186/1471-2180-12-42

Cite this article as: Riley et al:: Identification of genes expressed in cultures of $E$. coli lysogens carrying the Shiga toxin-encoding prophage Ф24. BMC Microbiology 2012 12:42.

\section{Submit your next manuscript to BioMed Central} and take full advantage of:

- Convenient online submission

- Thorough peer review

- No space constraints or color figure charges

- Immediate publication on acceptance

- Inclusion in PubMed, CAS, Scopus and Google Scholar

- Research which is freely available for redistribution

Submit your manuscript at www.biomedcentral.com/submit
Biomed Central 